\title{
Mapping of Groundwater Vulnerability Index in the Alluvial Plain of Semarang City Using the Susceptibility Index Method
}

\author{
Adetya Arga Marjuanto ${ }^{1, *}$, Thomas Triadi Putranto ${ }^{2}$, and Denny Nugroho Sugianto ${ }^{3}$ \\ ${ }^{1}$ Master Program of Environmental Science, School of Postgraduate Studies, Diponegoro University, Semarang - Indonesia \\ ${ }^{2}$ Geological Engineering Department, Engineering Faculty, Diponegoro University, Semarang - Indonesia \\ ${ }^{3}$ Department of Oceanography, Faculty of Fisheries and Marine Science, Diponegoro University, Semarang - Indonesia
}

\begin{abstract}
One of the negative impacts of settlements and urbanization is the decline in groundwater quality. In maintaining the sustainability of groundwater for a long period of time, a special study is needed, which can be done by examining groundwater vulnerability. The alluvial plain of Semarang City currently faces environmental problems such as degradation of groundwater quality which is the negative impact of the settlement, The purpose of this study was to examine groundwater vulnerability in the alluvial plain area of Semarang City. The Susceptibility Index method is using a spatial analysis tool based on rating and weighting value of some parameters, i.e. Depth of groundwater, recharge, aquifer media, slope, and land use. The result of this research reveals that about $41.3 \%$ area is covered under the high vulnerable zone, $50.3 \%$ area under moderately vulnerable zone and $8.4 \%$ area under the low vulnerable zone. 7 sub districts namely Tugu, Semarang Barat, Semarang Utara, Semarang Timur, Gayamsari, Pedurungan and Genuk, most of which are in the high vulnerability zone. Whereas the Ngaliyan, Semarang Selatan, Semarang Tengah, Candisari, and Gajah Mungkur, which are mostly in the low to moderate vulnerability zones.
\end{abstract}

Keywords: Groundwater; Vulnerability; Semarang; Susceptibility Index.

\section{Introduction}

Water is an important part of natural resources which has unique characteristics compared to other resources because water is renewable and dynamic. Because groundwater is one component in the circulation of water on the earth or the hydrological cycle, so groundwater can be renewed, but groundwater resources cannot necessarily be exploited without limits.

Groundwater is the largest use of freshwater resources by humans because the presence of groundwater is very abundant, easy to reach and good quality is one factor in the high interest of humans to make groundwater as one source of clean water. Groundwater is the most extracted resource in the world with an estimated extraction rate of $982 \mathrm{~km}^{3} /$ year [1]. In the area studied, groundwater is a very important resource because it is used to meet household, agricultural and industrial needs [2]. The main cause of world environmental problems today is from industrialization [3]. The development of the industry into an industrial revolution 4.0 will certainly have an impact on environmental quality, especially the use of groundwater [4]. As the most sought after water source, it is necessary to be careful in managing and utilizing groundwater.

Semarang City, which is on the main route point of the North Coast of Java Island, has made this city highly developed for industrial, trade and service activities [5].
The number of residents living in the urban area of Semarang City has reached $50 \%$ in the past 2010 and reached $60 \%$ in 2025 [6]. Semarang has potential hazards unlike other cities [7]. It is predicted that in the year 2030, the city of Semarang will experience a water crisis, this is due to the need for clean water by the industrial sector in 2010 around $90 \%$ of the water is taken from groundwater [8].

In maintaining the sustainability of groundwater for a long period of time, a special study is needed for the quantity and quality, one of the efforts in maintaining the potential and quality of ground water is by examining groundwater vulnerability [9]. The vulnerability of groundwater is generally formulated as an intrinsic influence [10]. The vulnerability of groundwater is the level of vulnerability of groundwater based on hydrogeological conditions. Vulnerability of Groundwater can be easily informed through the image media, namely map of groundwater vulnerability [11]. Groundwater vulnerability assessment is a tool that is able to guide land use planning decisions and to focus resources where they can be used most efficiently [12].

The basic concept of groundwater vulnerability is the greater or not the ability of rocks to be able to prevent the entry of groundwater contamination in a location. The water unsaturated zone above the aquifer is very influential in reducing the concentration of pollutants that will enter the aquifer [13]. The study of groundwater

\footnotetext{
* Corresponding author: adetyaarga88@gmail.com
} 
vulnerability is necessary in order to protect groundwater both in quantity and quality [14].

The purpose of this study is to examine the groundwater vulnerability zone on the alluvial plains of Semarang city with the geospatial approach and the Susceptibility Index (SI) method. SI which is the result of the development of the DRASTIC [15] method by [16] and from the results of [9], because the study proves that combining land use parameter in calculating vulnerability indexes can strengthen groundwater vulnerability assessment. Because land use can describe human activities such as excessive exploitation of groundwater, agriculture, and industry [17].

\section{Study Area}

The location of the research belongs to the administrator of Semarang Municipality with an area of $115.75 \mathrm{~km}^{2}$. Geographically located in $6^{\circ} 55^{\prime}-7^{\circ} 00^{\prime}$ Latitude and $110^{\circ} 17^{\prime}-110^{\circ} 30^{\prime}$ Longitude (Fig. 1). It is located in the alluvial plain of Semarang City and covering 17 subdistricts, namely Semarang Utara, Tugu, Semarang Tengah, Pedurungan, Genuk, Semarang Barat, Gayamsari, Semarang Timur, Gajah Mungkur, Candisari, Ngaliyan, and Semarang Selatan.

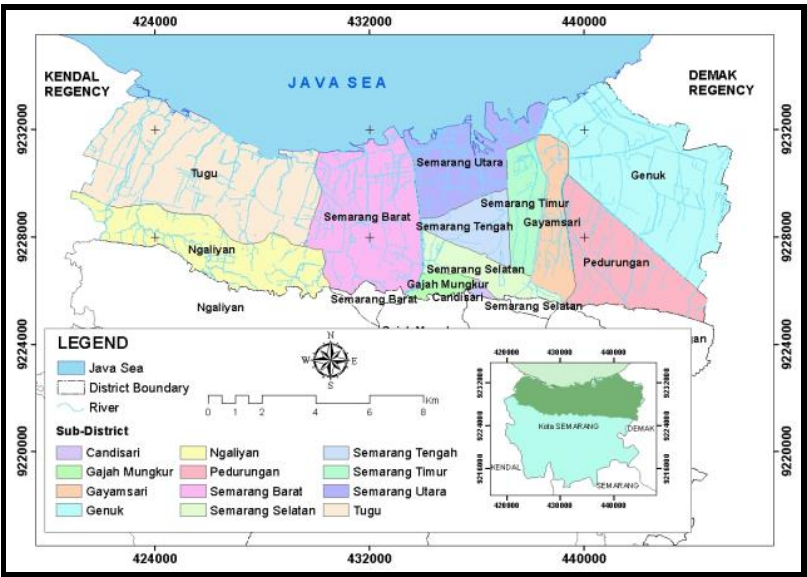

Fig 1. Study Area Map

\section{Research Method}

Stages of data processing using the geospatial method in this study to delineate the value of groundwater vulnerability based on several parameter maps combined. Actually many data concerning groundwater quality are required to identify groundwater [18]. In this case, the research uses the Susceptibility Index (SI) method developed by Ribeiro [16] and Stigter [9] which is adapted by Riyanto [14]. The parameters used to assess groundwater vulnerability are as follows:

1. Depth of Water Table (D)

2. Recharge (R)

3. Aquifer Media (A)

4. Slope (T)

5. Land Use (LU)

Each parameter has an effect in the assessment of groundwater vulnerability which is distinguished by the weight value. Parameters that have the highest weight value determine the level of groundwater vulnerability. The following are the weight values for each parameter according to those listed in Table 1.

Table 1. Weight of the Susceptibility Index parameter

\begin{tabular}{|c|c|c|}
\hline No & Parameter & Weight \\
\hline 1 & Depth of Water Table (D) & 0.186 \\
\hline 2 & Recharge (R) & 0.212 \\
\hline 3 & Aquifer Media (A) & 0.259 \\
\hline 4 & Slope (T) & 0.121 \\
\hline 5 & Land Use (LU) & 0.222 \\
\hline
\end{tabular}

While the ranking of each parameter is distinguished based on the rating of groundwater vulnerability, the classification of water table depth in Table 2 shows that the deeper the water table, the lower the potential for contamination.

Table 2. Classification of Depth Water Table

\begin{tabular}{|c|c|c|}
\hline No & $\begin{array}{c}\text { Depth Of Water Table } \\
\text { (meter) }\end{array}$ & Rating \\
\hline 1 & $<1.5$ & 100 \\
\hline 2 & $1.5-4.6$ & 90 \\
\hline 3 & $4.6-9.1$ & 70 \\
\hline 4 & $9.1-15.2$ & 50 \\
\hline 5 & $15.2-22.9$ & 30 \\
\hline 6 & $22.9-30.5$ & 20 \\
\hline 7 & $>30.5$ & 10 \\
\hline
\end{tabular}

The groundwater recharge classification in Table 3 shows that the smaller the groundwater infill, the lower the potential for pollutants to enter the groundwater.

Table 3. Classification of Recharge

\begin{tabular}{|c|c|c|}
\hline No & Recharge (mm) & Rating \\
\hline 1 & $<51$ & 10 \\
\hline 2 & $51-102$ & 30 \\
\hline 3 & $102-178$ & 60 \\
\hline 4 & $178-254$ & 80 \\
\hline 5 & $>254$ & 90 \\
\hline
\end{tabular}

The classification of groundwater aquifer media in Table 4 shows that if it gets higher the porous nature the higher the potential for pollutants to enter the groundwater.

Table 4. Classification of Aquifer Media

\begin{tabular}{|c|l|c|}
\hline No & \multicolumn{1}{|c|}{ Aquifer Media } & Rating \\
\hline 1 & Metamorphic/Igneous & 40 \\
\hline 2 & Sand & 80 \\
\hline
\end{tabular}

Slope classification based on the slope class in Table 5 shows that the lower of the slope class the higher possibility for pollutants to enter the groundwater. 
Table 5. Classification of Slope

\begin{tabular}{|c|c|c|}
\hline No & Slope (\%) & Rating \\
\hline 1 & $<2$ & 100 \\
\hline 2 & $2-6$ & 90 \\
\hline 3 & $6-12$ & 50 \\
\hline 4 & $12-18$ & 30 \\
\hline 5 & $>18$ & 10 \\
\hline
\end{tabular}

Land use classification in Table 6 shows the rank level of land use in influencing groundwater vulnerability. Human activities that have the potential to influence the condition of groundwater must be considered [19]. Land use is characterized by activities carried out by the community in certain types of land cover according to their activities [20].

Table 6. Classification of Land use

\begin{tabular}{|c|l|c|}
\hline No & \multicolumn{1}{|c|}{ Land use } & Rating \\
\hline 1 & Industry & 100 \\
\hline 2 & Paddy fields and annual crops & 90 \\
\hline 3 & Seaport & 80 \\
\hline 4 & $\begin{array}{l}\text { Train station, offices area commercial } \\
\text { activity, laid out green spaces }\end{array}$ & 75 \\
\hline 5 & Plantation & 70 \\
\hline 6 & Discontinuous urban areas & 70 \\
\hline 7 & Forest & 0 \\
\hline 8 & Water bodies & 0 \\
\hline
\end{tabular}

Processing of groundwater susceptibility was carried out by overlay using Arcgis 10.2 software to be mapped from the parameters of land use, slope, aquifer media, groundwater recharge, and groundwater depth which then multiplied the scores and weights according to Table 1, namely with the equation as follows:

$$
\begin{gathered}
\mathrm{SI}=0.186 \times \mathrm{D}+0.212 \times \mathrm{R}+0.259 \times \mathrm{A}+0.121 \\
\times \mathrm{T}+0.222 \times \mathrm{LU}
\end{gathered}
$$

The ratings are distributed in each class which is related to the level of SI range from "high" to "low" as shown in Table 7.

Table 7. Susceptibility Index

\begin{tabular}{|c|c|c|}
\hline No & SI & Vulnerability \\
\hline 1 & $36-53$ & Low \\
\hline 2 & $54-71$ & Moderate \\
\hline 3 & $72-89$ & High \\
\hline
\end{tabular}

\section{Results and Discussion}

\subsection{Results}

\subsubsection{Depth of Water Table}

The collection of groundwater depth data is carried out by measuring directly in the field. Measurements are made using a measuring tape. The technique of measuring groundwater depth is carried out by calculating from the ground to groundwater. Average values into groundwater are input into the Arcgis to be mapped. Based on the results of measurements in the field, it was found that the groundwater level in the alluvial plain of the Semarang, there were 7 classifications of groundwater level as illustrated in Fig. 2.

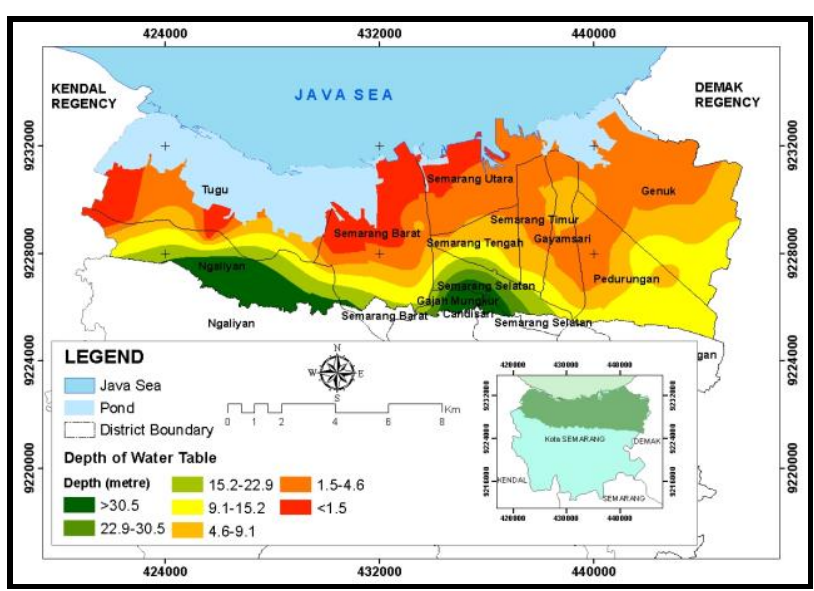

Fig 2. Depth of Water Table Map

As shown in the map, it can be explained that there are 7 classes of groundwater depth, shallow depths of groundwater starting from areas close to the sea while the deepest cover higher areas. Based on the classification shown in Table 2, shallow areas have the highest rating compared to deeper areas, because the factor of the deeper the groundwater then the possibility for contamination is lower.

\subsubsection{Recharge}

To find out the amount of groundwater recharge, rainfall data is needed and then calculate the recharge based on the formula. The rainfall data that is from Central Agency on Statistics Semarang Municipality from the year 2012-2017. After the recharge data has been calculated for the next stage map it using Arcgis as shown Fig.3.

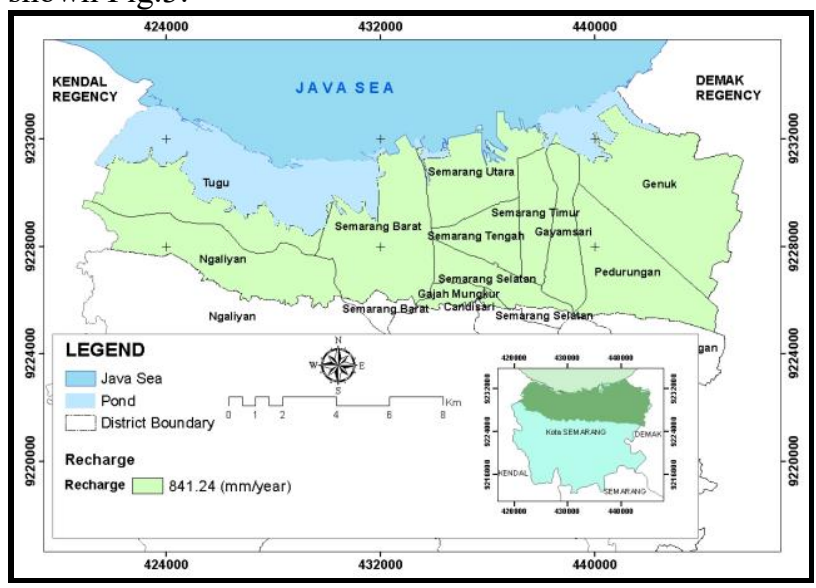

Fig 3. Recharge Map 


\subsubsection{Aquifer Media}

Because aquifer media will not change overtime, the aquifer media data can use from previous research, aquifer media in alluvial plains of Semarang city can be seen in Fig.4.

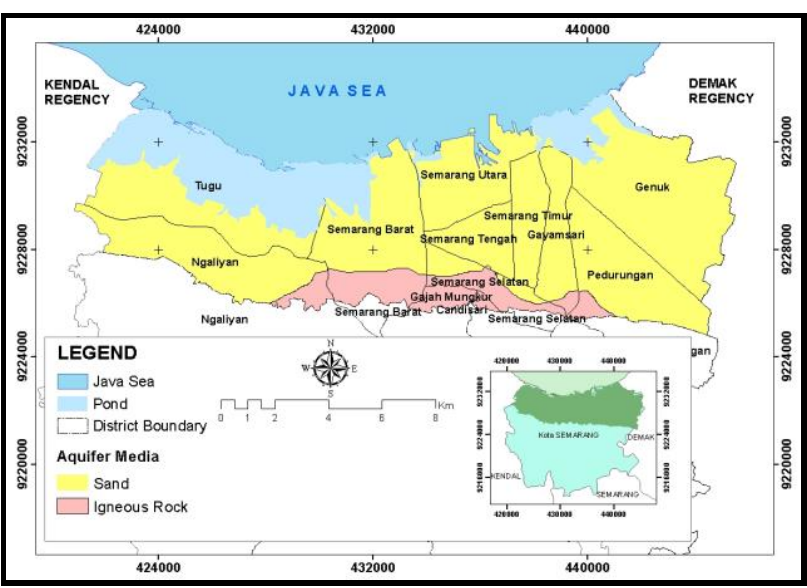

Fig 4. Aquifer Media

\subsubsection{Slope}

Slope data collection came from DEM. Slope data processing is carried out using Arcgis. The next stage of the slope is classified according to table 5. Slope analysis is based on the slope class. The lower the slope class the higher the potential for pollutants to enter the groundwater system, the slope in alluvial plains of Semarang city can be seen in Fig.5.

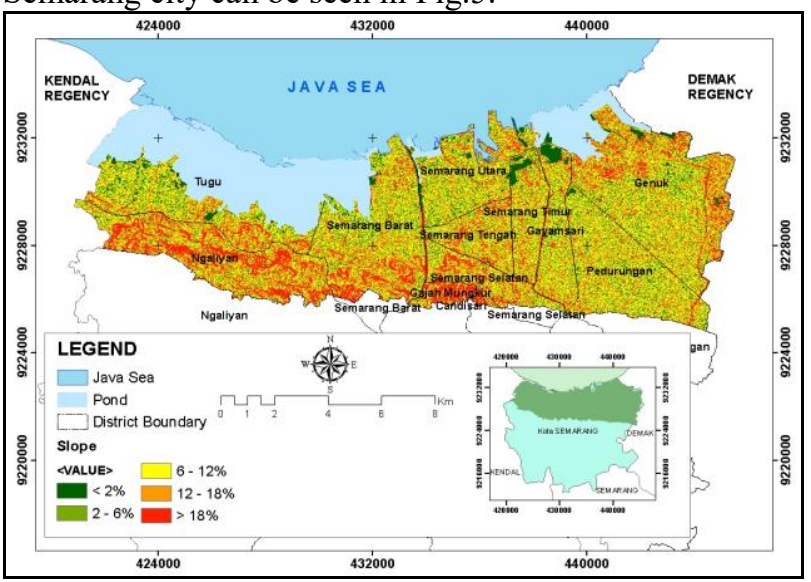

Fig 5. Slope Map

\subsubsection{Land use}

Land use data collection comes from updated agency data using the Google Earth image. The processing of land use data is done using Arcgis for its classification. Land use is given a score and weight according to Table 7. Analysis of land use is based on the highest score and weight. Land use in alluvial plains of Semarang city can be seen in Fig.6.

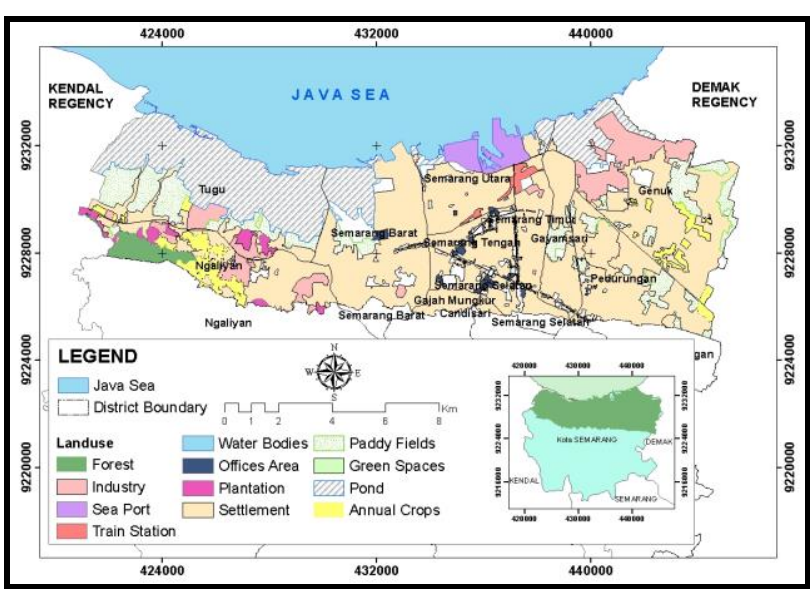

Fig 6. Land use

\subsubsection{Susceptibility Index}

After all maps have been given scores and weights in the Arcgis application by using the weighted overlay tool, we can calculate the SI, the SI map on the alluvial plain of Semarang city can be seen in the following Fig. 7.

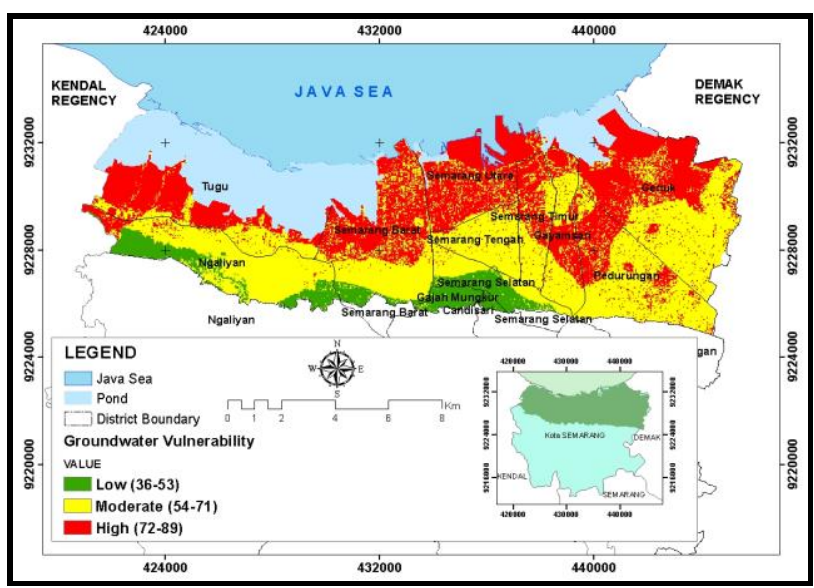

Fig 7. Vulnerability Index Map

The results of the overlay index obtained 3 classifications of vulnerabilities, namely low, medium and high. The area that has a high vulnerability is (4749.78 Ha), moderate (5788.79 Ha), and low (963.75 $\mathrm{Ha}$ ). Areas that were in the high vulnerability zone is $41.3 \%$ of the total study area, while the areas included in the moderate vulnerability classification included $50.3 \%$, and areas with low vulnerability classification included $8.4 \%$ of the entire study area.

\subsection{Discussion}

This study is a comprehensive effort to identify the vulnerability of groundwater in the alluvial plains of Semarang city which are at risk of being contaminated from population and industrial waste, to face the 4.0 industrial revolution, the study of groundwater vulnerability is very necessary, especially to determine industrial estate planning in urban areas. Semarang City as an economic center in the province of Central Java 
certainly needs this study to maintain the environmental sustainability. The densely populated city of Semarang, especially in the alluvial plains, was chosen for the case study. It is clear that the vulnerability assessment of groundwater is very important in sustainable groundwater resources [20]. In this context, the Susceptibility Index (SI) method is considered an easyto-use and comprehensive tool in the GIS Environment to identify the groundwater vulnerability in certain locations by spatial integration with various map layers. The Susceptibility Index (SI) method is considered to have been able for researchers to know about the vulnerability of groundwater by using parameters that are less than the other methods of groundwater vulnerability.

\section{Conclusion}

Based on the results of the study on the alluvial plains area of Semarang city, 7 Subdistricts namely Tugu, West Semarang, North Semarang, East Semarang, Gayamsari, Pedurungan and Genuk, most of them are in the high vulnerability zone. Whereas the Ngaliyan, South Semarang, Central Semarang, Candisari, and Gajah Mungkur, which are mostly in the low to moderate vulnerability zones. This shows that dense residential areas are zones where groundwater vulnerability is high, while areas that are natural areas such as forest and water areas are areas that have low groundwater vulnerability.

\section{Acknowledgements}

Authors are whishing thankful to the Ministry of Research, Technology and Higher Education of the Republic of Indonesia for the funding with the scheme of "Penelitian Terapan Unggulan Perguruan Tinggi" with the Contract No. 257-127/UN7.P4.3/PP/2019.

\section{References}

1. J. Margat, J.V.D. Gun, Groundwater around the World: A Geographic Synopsis (2013)

2. T.R.N. Amanah, T.T. Putranto, M. Helmi, Application of Cluster Analysis and Principal Component Analysis for Assessment of Groundwater Quality A Study in Semarang, Central Java, Indonesia, Conf. Ser. Earth Environ. Sci. 248, 12063 (2019)

3. P. Lacy, D. Waughray, Harnessing the Fourth Industrial Revolution for the Circular Economy (2019)

4. C. Stinson, 5 Ways the Fourth Industrial Revolution Could End Water Insecurity (2018)

5. N. Susanto, T.T. Putranto, H. Prastawa, Mapping the Water Usage Behaviour of Presto Milkfish Processing Industries in Semarang City, E3S Web Conf. 73, 3020 (2018)

6. T.T. Putranto, W.K. Hidajat, N. Susanto, Developing Groundwater Conservation Zone of Unconfined Aquifer in Semarang, Indonesia, in
IOP Conference Series: Earth and Environmental Science 55, 12011 (2017)

7. D.N. Yuliyani, T.T. Putranto, N. Indah, Study of Spatial Effect Distribution of Groundwater Quality on Rob Disaster in Semarang City, E3S Web Conf. 73, 3027 (2018)

8. A. Susanto, Conservation Strategy for Utilizing Groundwater as a Sustainable Source of Clean Water in the City of Semarang, Semnas Nasional FMIPA-UT, 1-11 (2010)

9. T.Y. Stigter, L. Ribeiro, A.M.M.C. Dill, Evaluation of an intrinsic and a specific vulnerability assessment method in comparison with groundwater salinisation and nitrate contamination levels in two agricultural regions in the south of Portugal, Hydrogeol J 14, 79-99 (2006)

10. T.T. Putranto, N. Santi, D.A. Widiarso, D. Pamungkas, Application of Aquifer Vulnerability Index (AVI) Method to Assess Groundwater Vulnerability to Contamination in Semarang Urban Area, MATEC Web Conf. 159, 1036 (2018)

11. J. Vrba, A. Zaporozec, Guidebook on Mapping Groundwater Vulnerability, 16th ed. IAH International Contributions to Hydrogeology (1994)

12. G. Bekesi, J. Mcconchie, The Use of AquiferMedia Characteristics to Model Vulnerability to Contamination, Manawatu Region, New Zealand, Hydrogeol. J. 10, 322-331 (2002)

13. B.L. Morris, A.R.L. Lawrence, P.J.C. Chilton, B. Adams, R.C. Calow, B.A. Klinck, Groundwater and Its Susceptibility to Degradation: A Global Assessment of the Problem and Options for Management, United Nations Environment Programme 03(3) (2003)

14. I. A. Riyanto, M. Widyastuti, Intrinsic Vulnerability and Groundwater Specifications to Pollution in Banjarnegara District and Surroundings, J. Bumi Indones. 5(4), 1-17 (2016)

15. L. Aller, T. Bennet, J.H. Lehr, R.J. Petty, G. Hacket, A Standardized System For15 Evaluating Ground Water Pollution Potential Using Hydrogeologic Settings, United State: U.S. Environmental Protection Agency (1987)

16. L. Ribeiro, E. Serra, E. Paralta, J. Nascimento, Nitrate Pollution in Hardrock Formations: Vulnerability and Risk Evaluation by Geomathematical Methods in Serpa-Brinches Aquifer (South Portugal), Proc IAH International Conference on Groundwater in Fractured Rocks, 377-378 (2003)

17. T. Putranto, W.K. Hidajat, H. Wijaya, Hydrochemical Assessment of Unconfined Aquifer System in Bayat Melange Complex, Klaten, Indonesia, Int. J. GEOMATE 13, 17-24 (2017)

18. T.T. Putranto, A.H. Qadarisman, N. Santi, Najib, Groundwater Quality Analysis in Nusakambangan Groundwater Basin/Indonesia, E3S Web Conf. 73, 4024 (2018)

19. N. Susanto, T.T. Putranto, D.A. Widiarso, Preliminary Study of the Human Activities and 
Perception on the Groundwater Conservation in Lowlands of Semarang, MATEC Web Conf. 101, 4003 (2017)

20. T.T. Putranto, D.E. Aryanto, Spatial Analysis to Determine Groundwater Recharge Area in Purworejo Regency, Central Java Province/Indonesia, E3S Web Conf. 73, 3025
(2018)

21. J. Wang, J. He, H. Chen, Assessment of Groundwater Contamination Risk Using Hazard Quanti Fi Cation , A Modi Fi Ed DRASTIC Model and Groundwater Value, Beijing Plain , China, Sci. Total Environ. 432, 216-226 (2012) 